\title{
The impact of privatization policy on the economic performance of the Establishment in Sudan (Case Study on SATA Company)
}

\author{
Mohammed Abdalla Mohammed Ahmed \\ Dr, Associate Professor of Economics Imam AlMahdi University/faculty of Economic and Administrative \\ Sciences, Sudan
}

\begin{abstract}
The paper aims at identifying the general performance of the public institutions, their production efficiency, profitability and financial performance after transferring their ownership to the private sector. It also aims to clarify the efficiency of private sector institutions in employing their financial and human resources better than public sector institutions.

This paper is based on the following hypotheses:

Changing ownership leads to the promotion and increased commercial competition of state-owned enterprises, resulting in improved financial performance and productive efficiency.

The profitability of state-owned enterprises is lower than the profitability of privately owned enterprises. Private sector organizations attract and use their financial and human resources more efficiently than public sector institutions. The paper used the descriptive and comparative analytical methodology in order to evaluate the performance of the company before and after its transfering to the private sector, the data is analyzed using various financial analysis tools such as profit and debt ratio and total return on assets.

The Paper depends on many sources for data collecting such as interviews with the company adminstration, company workers, beside the secondary sources such as books, references, periodical, university theses and working papers. The paper included four axes which contain: introductory part, the Paper theortical frame work, privatization experience in the Sudan, in addition the case study before and after privatiztion, beside the results and recommendations. The Paper finding that privatization of the company realized some positive results such as the increase in the company rates of the profitability and the improvement of the efficiency of productivity, However from the other side it contributed in increase of unemployment, and did not contribute positively neither to the national income nor to the improvement of balance of payments.
\end{abstract}

Keywords: Privatization, economic reform, productive efficiency, structural adjustment, public sector, private sector.

JEL classification: K23, G00, G18.

Cite as: Ahmed, M. Ab. M. (2019). The impact of privatization policy on the economic performance of the Establishment in Sudan (Case Study on SATA Company). Financial Markets, Institutions and Risks, 3(3), 98112. http://doi.org/10.21272/fmir.3(3). 98-112.2019.

(C) The Authors, 2019. This article is published with open access at Sumy State University.

\section{Introduction}

The observer of the evolution of developmental thought and developmental policies since the late seventies, observes the extent of the changes witnessed by many economies of the world in the last two decades of the twentieth century.

It was behind this transformation that led to the emergence of the so called conservative or neo-liberal revolution, which considered that all economic problems (inflation, budget deficit, indebtedness, unemployment) were due largely to the state's intervention in economic life, Which led to the adoption by these countries of new development policies based on market economics, economic freedom, non-interference of the state in economic activities, and reduction of government spending through the elimination of public sector institutions and productive activities and losing To support against it and convert it to the private sector; and besides stand international financial institutions to provide economic policy conditional loans, aid and technical assistance to countries to adopt these reform policie .Therefore, these economic changes have cast a shadow over the Sudanese economy and the public sector institutions on which the state depends on pushing 
the process of economic development, which are operating according to the more contradictory guidelines, because they are often forced, for social or political reasons, to sell or deliver the goods and services they produce at prices below Production costs and the use of factors of production are not the most available and not the most cost-effective factors. As a result, many institutions have been operating at a loss and are depleting the State's general budget. The state has been forced to take steps and reform policies that are based on the adoption by the state of the policy of economic liberalization and the implementation of the policy of privatization in order to raise the productive efficiency of public sector institutions, improve their performance, reduce the role of the state in economic life and expand the participation of the private sector in economic activity.

\section{Paper Objectives}

1/ Identify the general performance of public institutions and their productive efficiency after transferring their ownership to the private sector.

2/ Statement of profitability of public sector institutions and their financial performance after transfer to the private sector.

3/ To clarify the efficiency of private sector institutions in employing their financial and human resources.

Paper Assumptions: -1The change of ownership leads to the promotion and increased trade competition of state-owned enterprises, resulting in improved financial performance and productive efficiency.

-2The profitability of state-owned enterprises is less than that of privately owned enterprises.

-3 That private sector institutions attract and use their financial and human resources more efficiently than public sector institutions.

\section{Methodology of the paper}

The paper follows the comparative analytical descriptive method in which the performance of the company is evaluated and compared to two periods before and after privatization. The data is analyzed using various financial analysis tools such as profit and debt ratio and total return on assets. The study relies on primary and secondary information, The primary information is through interviews with the company's management and employees. Secondary information is collected from the departments, reports and documents related to the company.

\section{Organization of the paper}

The paper included four axes: The first axis: The theoretical framework of the study includes the general concept of privatization policy, objectives and motives, and the relationship of privatization to economic reform. The second axis deals with privatization in Sudan. The third axis: A historical overview of the origins of SATA and its general performance before privatization and evaluation of the performance of the productive and financial company. The fourth axis deals with evaluating the performance of the company after privatization, in addition to the conclusions and recommendations of the study.

\section{Theoretical framework}

General concept of privatization .The idea of privatizing the neoclassical school came out by calling for the liquidation of state ownership of public companies and institutions as one of the solutions to get out of the crisis of inflationary recession in the seventies of the last century. Hence the idea of privatization began to appear in modern writings and conflicting meanings and multiple concepts that try to determine the meaning of privatization, and revolves around these concepts on several trends, including the following::(Said Alnajjar).

.1Privatization means: transferring a business from ownership or management of the public sector to the private sector, or by transferring ownership and control from the public sector to the private sector, especially through the sale of assets.

2.Privatization means :cutting the public sector, expanding the private sector, and increasing its role within the economy. This is achieved through the state's liquidation of the public sector (wholly or partially) or through leases and concessions.:)Mohammed Al-Tayeb, 2001, p. 52..( 
.3Privatization is a means: to get rid of the losing units in the public sector, which means that by turning these units into the private sector will achieve higher productivity and profitability. Britain and Australia were among the leading countries that applied this concept in order to lift the national economy out of its stakes by eliminating the state's economic institutions To the private sector or encourage them to engage in it.)Ahmed Maher, 2002, p. 24(.

The United Nations Development Program (UNDP) defines privatization as a shift in favor of a market economy and is transformed by the following steps:

A - Adopting economic policies that support the market economy. These policies are to strengthen the institutional framework of the market economy and to follow the policy of economic liberalization, which opens the way for the private sector to develop resources and manage economic activity.

B. Development of the private sector This stage is very important in developing the services needed by the private sector. It includes the regulation of monetary and financial policies that support and encourage the development of the private sector and its institutions such as chambers of commerce and industry,

C- Privatization of the public sector after the private sector is able to lead the public sector enterprises that are intended to be disposed of. The privatization process is carried out through the following:)Mohammed alTayeb, op. Cit., p.52(.

1.Sale of public buildings in whole or in part through the issue of shares.

.2Sell in open auctions.

3.Participation of the private sector in the management of public enterprises.

4Renting public facilities for the private sector.

Accordingly, we find that the word Privatization is a term that refers to the transfer of ownership or management of public institutions to the private sector for the purpose of improving the efficiency of the economy. It is a package or package of integrated policies aimed at raising production efficiency and activating and expanding the competition in the production and marketing of all Goods and services by liberalizing the market from public monopolies whenever possible.(Said Ismail).

Therefore, privatization is not limited to the idea of selling public sector units that are losing or winning to the private sector, but rather is broader and deeper. Therefore privatization is not the process of transforming public enterprises into private ones, regardless of the policies that are integrated economically, financially, And legally, but all in one package and in a coherent strategy for the development of the national economy.)Workshop on Privatization in Sudan.

\section{2 .Relationship of Privatization and Economic Reform:}

The worsening economic crises in the developing countries, the Soviet Union and the Eastern European countries led to the need to adopt new economic reform programs that include the policies of economic restructuring and liberalization, which can be authorized in the following):Said Alnajjar:, 1988.op. Cit., p..(15

/ 1Edit prices of goods and services in the market

2 / Liberalization of the labor market

/ 3Liberalization of foreign trade

4 / Liberalization of the financial and monetary systems

/ 5transformation from public ownership to private property

In view of the economic reform policies above, it is clear to us that privatization policy is one of the forms of economic reform, which aims to rely on individual efforts and the private sector in a broader and fundamental way. On the grounds that the economic reform aims at the direction of the launch of market mechanisms and individual efforts and initiatives of the private sector and expand the scope of competition and the withdrawal of the state from economic activity to the system of free economy.) Mohamed Hashim Awad. 
In this concept of privatization and economic reform we see privatization policy as a cornerstone of economic reform, which only achieves its objectives if privatization goals are achieved by turning public ownership into private ownership and achieving a free economy based on individual efforts and competition.

\subsection{The privatization :Objectives and motives:}

.13.1.Objectives of privatization. Privatization programs that are pursued by governments vary in purpose and purpose. Each government sets goals that are appropriate to the economic conditions surrounding it. However, there are three main objectives agreed upon. The countries that adopted this policy are:)Workshop on Privatization in Sudan,1997, p ... 9

The first objective :is economic efficiency which is believed to be achieved in two ways:

The privatization policy seeks to increase the efficiency of resource allocation by increasing competition and reducing monopolistic tendencies.

The privatization policy works to improve the efficiency of productive projects, in other words, to optimize the production inputs of the establishment.

The second objective: privatization seeks to ease the financial burdens borne by the state. The disposition of public institutions, especially the losers, exempts the state from the burden it sustains in supporting these institutions.

Third Objective :Privatization programs seek to develop and strengthen the private sector and enhance its role in the national economy.

1 3.2 .Motives. The deterioration of the performance and efficiency of public institutions has received considerable attention from international organizations such as the World Bank, the International Monetary Fund and the International Development Agency. However, this interest has not been met with the satisfaction of some economists. It was thought that interest in the transfer of public ownership to the private was due to objective But for reasons of political ideology.)Taj al-Din Ibrahim Hamid. Where financial institutions are providing their assistance conditional on their economic policies, especially with regard to their progress towards privatization of the public sector. When aid is provided for development projects, private sector participation should be encouraged or required wherever possible.(Steve Hankey: Transforming Public Property into Private.

The financial institutions and some creditor countries use the debt arm to impose on the debtor countries the structural adjustment policies, which are based on the withdrawal of the public sector from productive activities, the release of market forces and the liberalization of prices, in order to induce the debtor countries to commit to reducing government expenditure as a condition for obtaining loans and financial aid).Dia Majid :Privatization and Structural Corrections. Thus, we find from the above that transfers of public property to the private sector are going hand in hand with aid and loans for development and macroeconomic policy reform.

\section{Privatization in Sudan}

After independence in 1956, the Government of Sudan inherited a number of public institutions from the colonial government, such as the Al-Jazira Project, the Sudan Railway, the National Electricity Authority and other public facilities and institutions. Subsequently, the successive governments of Sudan set up production units of the public sector, with the aim of achieving economic development, which consisted in the establishment of some agricultural projects and a number of infrastructure projects. In 1960, the ten-year plan for economic and social development was adopted, which called for the government to enter the investments that lack the courage and initiative of the private sector .Accordingly, nine factories were established in the sugar, meat, dairy, fruit and vegetable sectors.

The 1970s also witnessed the beginning of a new economic era in the country. The state then seized a large number of national and foreign private institutions through nationalization, and the state also increased its productive activities, especially in the field of industry, agriculture and services).Mohammed al-Tayeb, op. Cit., p.(35.). Although the goal of establishing public sector institutions prior to independence was linked to meeting the needs of the British economy from the provision of raw materials in that era, these institutions later became one of the main pillars of the economy of Sudan, which aims to achieve the objectives of 
increasing the value added of the Sudanese national economy These objectives include the following:)Fatma Ahmed Mohamed, Unpublished Master Thesis, 199 5, p. 32.

-1 Provision of consumer goods necessary for domestic consumption.

2-Increase the total production in the national economy and raise productivity.

-3 Create real financial resources to support public revenues.

4 - Achieving the policy of replacing imports with local production.

Therefore, these public institutions played a major role in the national economy, contributing about $90 \%$ (agricultural projects, railways, electricity and water services). And contributed about $40-50 \%$ of the national product and about $75 \%$ of the total exports and $70 \%$ of the total workforce in the country until the total number of public institutions in Sudan about 190 public facilities in the early nineties distributed as follows:

Table 1. Distribution of public sectors in Sudan

\begin{tabular}{|l|c|}
\hline \multicolumn{1}{|c|}{ Scator } & Number \\
\hline Agriculture Scator & 17 \\
\hline Industry Sactor & 32 \\
\hline Energy and Services Scator & 15 \\
\hline Transportation Scator & 9 \\
\hline Participation Scator & 71 \\
\hline Banks of Government & 6 \\
\hline Institutions owned by State & \multicolumn{1}{|c|}{40} \\
\hline & Total \\
\hline
\end{tabular}

Source: Report of the Technical Committee for Evaluation of Facilities of the Public Sector, Companies and Institutions Council of Ministers, July 1992.

However, the manifestations of failure have started in the public institutions in Sudan since the mid-seventies, where the letter of the general budget in 1974/1975 to the inability of some public institutions to meet their financial obligations, which forced the state to introduce the budget deficit item to meet, but the outlook to address this failure May be likened to the discrepancy (between reforming and urging the elimination of losing institutions and standing with support for these institutions for ideological reasons). Mohammed al-Tayeb. The deterioration and poor performance of public institutions in Sudan continued until the early 1990s, some of which failed to achieve any profits or even rely on their resources in some cases. Therefore, the government found itself compelled to support these institutions from the public budget to stand on their legs or even to have to lay off their employees. )Naamat Al-Fadil, Working Paper on Privatization in Sudan,199 7, p. 3. (As a result, the state allocated 2.5 million pounds in the item (supporting institutions and bodies) in the budget of the year 1974/1975. This item remained until 1992/93 after the adoption of the policy of privatization by the state).Report of the Technical Committee.

Table 2. Support directed to public institutions and bodies in the Sudan in one million pounds in the period 1989-1993.

\begin{tabular}{|c|c|c|c|c|}
\hline Items & $89 / 90$ & 90/91 & 91/92 & $92 / 93$ \\
\hline Total public expenditure & 12159 & 15859 & 53446 & 74607 \\
\hline The amount of support directed to public institutions in sudan & 328.5 & 1258 & 115 & 200 \\
\hline Porpotion of directed support to public institutions in sudan & $2.7 \%$ & $0.8 \%$ & $0.2 \%$ & $0.3 \%$ \\
\hline
\end{tabular}

Source: Report of the Technical Committee for Public Utilities in 2000.

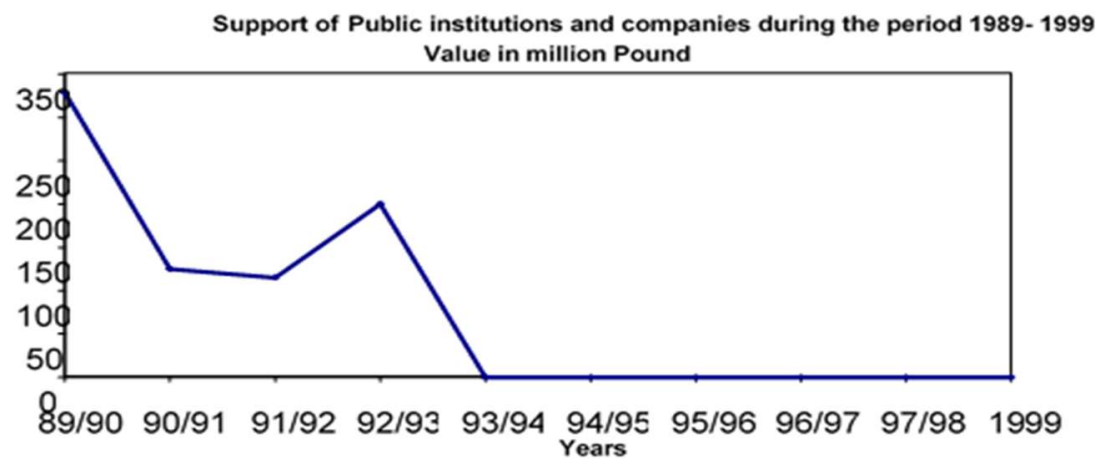

Figure 1. Support of Public institutions and companies during the period 1989- 1999

Source: completed by author. 


\section{1 .Experience of privatization in Sudan}

The recommendation was that the State adopt the policy of privatization within the program of economic liberalization policy in 1992, which called for the state to exit the economic activity through the sale of public institutions that are losing or stumbling, selling state shares or transferring them to public shareholding companies, The Sudanese economy, represented by the poor performance of public institutions and their lack of contribution to the support of the State Treasury, aimed at influencing aggregate demand and combating inflation.

In 1990, before the implementation of the policy of economic liberalization, the Council of Ministers formed a committee to study the situation and public performance of the institutions that follow the public sector (within the tripartite program of economic rescue 1990-1993). The committee reached the following conclusions: )Report of the Technical Committee ,2000, p. .(2

1 - Not to make any profits in these institutions, but often lose losses.

- 2The complexity of financial and administrative procedures.

3 - its dependence on government support in full.

-4 Poor distribution of services provided to the public by them.

This was followed by the announcement of the tripartite program of economic rescue 90/1993 which was aimed at achieving some goals including:

Remove the administrative, economic and legal obstacles to businessmen and local and foreign investors to work under the following policies and procedures:

1 -Adopt privatization policy by abolishing the monopoly of the state in the fields of agriculture and industry, internal and external marketing and services.

2 -The exit of the state from these areas through the sale of losing and troubled institutions or the sale of shares of state ownership or transfer them to public shareholding companies involving the private sector and foreign.

3 -Amendments to all laws governing economic activity, taxes, customs and labor.

4 -Starting with the liberalization of export prices and the gradual liberalization of the prices of goods, services and imported goods.

5 -Make adjustments in the structures and foundations of bank financing.

Accordingly, the Public Utilities Act was promulgated, and then a higher committee was set up to act on public utilities and define their powers and technical powers.

From 1995 until 1995, 75 of the 151 facilities to be disposed of were disposed of. The agricultural sector was one of the largest sectors privatized by $28 \%$, followed by the industrial sector by $24.6 \%$ The commercial sector $21.1 \%$, and the transport, communications and public communications sector by $19.3 \%$.

\subsection{Criteria and procedures of privatization in Sudan:}

The experience of privatization in Sudan has been institutionalized and has been accompanied by many legal and regulatory measures, which are as follows: Report of the Technical Committee ,op. Cit., 2000, p. .(2

1 -Issuance of the Public Sector Utilities Act by the Council of Ministers in.1990

-2The establishment of the Supreme Committee for the disposal of public sector facilities and the determination of its jurisdiction and powers.

3 -The formation of technical committees and specialists who carry out evaluation work for public projects.

In order to implement this policy, a committee has been formed to formulate specific recommendations on the institutions that may continue under the umbrella of the public sector and those that are privatized or liquidated. The guidelines of this committee are as follows:

1 -Legal status and institutional and structural structure. 
The main objectives of these institutions in terms of commercial or service.

2 -The importance of the institution from the national point of view (whether it is strategic or not.(

3-The Supreme Committee adopted the recommendations of the committees and the guidelines that it worked on and decided that the behavior of the public sector institutions is based on two axes :Report of the Technical Committee ,op. Cit,. 2000, p. 3.(

-1The effectiveness of financial performance, measured by indicators related to profitability, value added and manpower.

2 -The strategic importance is (national security and economic and social strength.(

The Higher Committee for the Management of Public Sector Facilities has adopted criteria for selecting the units to be privatized, which are shown in the table below:

Table. 3 Criteria for privatization of public institutions in Sudan

\begin{tabular}{|l|l|l|}
\hline Exent of eonomic strength & Strategic importance & Decision \\
\hline Establishments with financial and economic power & Strategic and socially important & Remain publicly owned \\
\hline Establishments with financial and economic power & Non Strategic and social important & Tansformaion of the private sector \\
\hline Establishments with no financial or economic power & Strategy and not of social importance & $\begin{array}{l}\text { Tansformaion } \\
\text { companies) }\end{array}$ \\
\hline Establishments with no financial or economic power & $\begin{array}{l}\text { Non Strategic and not of social } \\
\text { importance }\end{array}$ & Filtered \\
\hline
\end{tabular}

Source: Report of the Technical Committee for Public Utilities in 2000.

All these measures have enabled the experiment to start a sound start . The privatization program in Sudan was implemented in 32 out of 57 facilities disposed of during the period 1992-1997, representing 56\% (25) facilities disposed of by diversion, representing 44\%. And the period from 1998 to 2000 , which saw the allocation of about 14 of the facilities included in the program, which represents about $50 \%$, as shown in the following table.

Table 4. Sectors and Privatization Forms Utilities Public sectors in Sudan from 1992-1997.

\begin{tabular}{|r|c|c|c|c|c|c|c|}
\hline $\begin{array}{r}\text { Sactor } \\
\text { Formla }\end{array}$ & Industry & Agriculture & $\begin{array}{r}\text { Transportati } \\
\text { on }\end{array}$ & $\begin{array}{r}\text { Energy } \\
\begin{array}{r}\text { Comercial } \\
\text { varied }\end{array}\end{array}$ & $\begin{array}{r}\text { Total } \\
\text { persantag } \\
\text { e }\end{array}$ \\
\hline Sell & 8 & 1 & 4 & 2 & 1 & 16 & $28 \%$ \\
\hline Participation & 1 & - & 2 & - & - & 3 & $5.3 \%$ \\
\hline Rent & - & - & 1 & - & - & 1 & $1.8 \%$ \\
\hline Restructuring & - & 4 & - & - & - & 4 & $7 \%$ \\
\hline Public Companies & - & - & - & - & 2 & 2 & $3.5 \%$ \\
\hline Filtering & - & 6 & - & - & - & 6 & $10.5 \%$ \\
\hline Devolution & 5 & 5 & 4 & 2 & 9 & 25 & $43.9 \%$ \\
\hline Totally & 14 & 16 & 11 & 4 & 12 & 57 & \\
\hline
\end{tabular}

Source: Report of the Technical Committee for Public Utilities in 2000.

\section{Historical background of the company:}

The company started its services in Sudan in 1937 in Port Sudan as a trading company engaged in the distribution and marketing of shoes, which was founded by Mr. Bata (Czech nationality). But the company began its actual production of cloth shoes known as Bata shoes in the 1950s when they rented buildings for this purpose in the Khartoum industrial zone.

In 1962, Bata was established as a private company owned by Bata International Group of Companies with a capital of one million seven hundred thousand Sudanese pounds. The factory was built and new sections were added to produce plastic shoes, sponges and leather shoes.

In 1978, an agreement was signed between Bata International and the Ministry of Industry, whereby Bata entered into a partnership with Bata, the nationalized company which was a branch of Bata International until 1970 when it was nationalized. Under this agreement, Bata signed a 51\% And 49\% of the shares of the Government of Sudan and the company was registered under the Companies Act of 1925. (Kabbashi Nasser: Director of Marketing Department, SATA, interview dated 21/9/2003). 
In 1986, Bata International sold its shares to the Government of Sudan, represented by the Ministry of Finance, the Sudanese Development Corporation and the Investment Company, where the shares were distributed as follows:

1. The Government of the Sudan and the Ministry of Finance $71 \%$

2. Sudanese Development Foundation 23.2\%

3-Kerry Investment Company 5.8\%

Total shares $100 \%$.

Accordingly, the name of the company was changed from Bata Sudan Co .Ltd. to the Sudanese Company for the production and distribution of shoes) Sata).(Memorandum of sale of SATA and Blue Nile Packaging Company, prepared by Mubarak Khaled Musa, Coordinator of the General Industrial Sector, 1994 , p.6.(

\subsection{SATA Corporation Purposes and Objectives:}

\subsubsection{Purposes:}

The Sudanese Company for the production and distribution of shoes (Sata) was established under the Companies Law of 1925. The Articles of Association set out the purposes of establishing this company in paragraph (3), which reads as follows:

.1The company shall deal industrially and commercially in all types of natural and industrial leathers, in the inputs of the leather industry and all related to it, industry and trade.

2.To deal industrially and commercially in the production of shoes, leather materials and other inputs of production and all related to manufacturing and trading by various means, and also to carry out trading, distribution, authorization and supply by all means in all products of the company.(A study on the performance evaluation, Ministry of Industry, 1988 ,P.8.(

\section{1. .2Objectives :}

1.The company's involvement in providing the needs of citizens and regular troops of shoes and low prices.

.1Follow the import substitution policy for shoes and at reasonable prices provide the country with hard currencies that would go to import these shoes from abroad.

.3Providing more jobs and employment.

\section{3..2 General performance of the company prior to privatization:}

\subsubsection{Technical status of the plant:}

The factory consists of four production units for the production of plastic shoes, cloth, sponges and leather shoes. The design capacity of the factory is estimated to be about 6.300 .000 pairs. It has an actual capacity of 4.650 million pairs of shoes per year on average.

The number of employees at the company when it was established in 1962 was estimated at about 1000 workers. However, the number of employees in the company decreased after that, due to the discontinuation of some machines in the factory and the inefficiency of some others until the number of employees in the company in 1988 reached about (623) (278) direct labor for production (275) employees and (70) service workers.)A study on the performance evaluation, Ministry of Industry ,1988 ,op. Cit.,P.8.(

Table 5. The design and actual energy and the factory-made boilers in 1962.

\begin{tabular}{|r|r|r|r|}
\hline Department & Design power & Actual energy & Daily production \\
\hline & & 4500 & 8000 \\
\hline Plastic & 6000 & 3000 & 6000 \\
\hline Cloth & 5000 & 4000 & 10000 \\
\hline Sponges & 5000 & 4000 & 680 \\
\hline Leather & 5000 & 15500 & 24680 \\
\hline Total & 21000 & & \\
\hline
\end{tabular}

Source: SATA Performance Evaluation Company, 1988. 


\subsubsection{Production:}

The company produces plastic, cloth and leather shoes, which are estimated to cover the company's production, of which about $16 \%$ of the volume of demand in the local market, estimated at 25 million pairs of shoes per year, according to statistics of the Ministry of Industry in 1988.

Table 6. The company produced shoes during 1982-1987

\begin{tabular}{|c|c|c|c|}
\hline year & $\begin{array}{l}\text { Total Pordution during the } \\
\text { Year }\end{array}$ & Performance based on Design power & $\begin{array}{rrrr}\text { Performance based on } \begin{array}{r}\text { actual } \\
\text { energy }\end{array} \\
\end{array}$ \\
\hline 1983 & 2387600 & $38 \%$ & $51 \%$ \\
\hline 1984 & 2148000 & $34 \%$ & $46 \%$ \\
\hline 1985 & 1262000 & $20 \%$ & $27 \%$ \\
\hline 1986 & 1383000 & $22 \%$ & $30 \%$ \\
\hline 1987 & 1499000 & $24 \%$ & $32 \%$ \\
\hline
\end{tabular}

Source: SATA Performance Evaluation Company, 1988.

The decrease in the production capacity of the company during the years.

(1983-1987) is reflected in the above table. This decrease was reflected in the utilization of the company's production capacity, which fluctuated between the highest ratio in 1983 and the lowest in 1985. This decline in the company's production And the extent of the exploitation of production capacity to some of the difficulties and problems faced by the company and represented by the following ::)Mohammed al-Tayeb, op. Cit., P.10(7.

-1Bureaucracy: The laws and regulations that restrict the freedom of decision-making,For example, if the company wants to buy raw materials, this requires the approval of the Ministry of Finance and the Bank of Sudan, which takes a long time, which may lead to the company being unable to fulfill its commitment in the field of production.

-2Lack of cash: The government usually can not meet its financial obligations to the company on time, making the company unable to develop long-term plans.

-3The deterioration of the production capacity of the machines due to the end of their useful life in addition to the acute shortage of tools and some of them were presented as plastic and wooden molds.

\subsubsection{Company Productivity Efficiency}

In order to measure the efficiency of the productive company, we can use several methods, so that the method of average productivity of the material worker is considered the easiest and most accurate method. According to this method, the average productivity of the worker can be calculated as follows:

Average productivity of the worker $=$ the quantity of output or output divided by the number or size of labor used.

Table 7. Production of workers in the various production departments of the company in the first half of 1987

\begin{tabular}{|c|c|c|c|}
\hline Department & Number of Workers & Production within 6 Months & $\begin{array}{c}\text { Workers' wages in 6 months in } \\
\text { dinars }\end{array}$ \\
\hline Plastic & 105 & 336400 & 140502.6 \\
\hline Cloth \& Sponges & 128 & 332750 & 171279.4 \\
\hline Leather & 45 & 74580 & 60215.4 \\
\hline Total & 278 & 743730 & 371997.4 \\
\hline
\end{tabular}

Source: SATA Performance Evaluation Company, 1988.

The average productivity of the worker in each of the divisions of shoes (plastic, cloth and leather) was 533, 433 and 276 pairs per month respectively, indicating the extent of the decline In the efficiency of the productive company which is highly attributed to the following:

-1The factory machinery was introduced and its production capacity deteriorated, which was reflected in the low production rates and thus the efficiency of the production company.

2 -The increase in the number of employees in the company's production departments, which was the result of the advanced technology of the plant's machines, and the required increase in the number of workers, which led to the low productivity of the worker.

-3The work of a single rosette and pinks in some production departments of the company instead of the three shifts as a result of the low efficiency of the factory machines and some of them stopped working. 


\subsubsection{Financial Performance of the Company}

Financial performance is one of the most important indicators for the company, and how to know the eligibility of the company to stay, and the extent of achieving the objectives of the investors, and here we are interested in identifying the following rates :)Fred Weston and Yohine Burjam.

\section{1 -Rates of indebtedness}

This indicator measures the extent to which the company relies on the debt to finance its activities and the extent to which creditors contribute to the company's total assets. In other words, it shows the amount of capital contributed by the owners compared to the loans contributed by the creditors in the total assets of the company. The rate of indebtedness here is the size of indebtedness attributed to the total assets of the company, where the rate fluctuated between the highest level in 1983, which amounted to about $168 \%$, indicating that the size of debt for the total assets of the company exceeded the average rate of industry accepted globally, $33 \%$. Therefore, the company will have difficulty in obtaining additional debt to finance its activities in the future unless its debt rates are reduced first. However, as a result of the re-registration of the company in 1985, this rate dropped to reach only $10 \%$ in 1987 , due to the revaluation of the company's assets and the repayment of Bata's debts.

\section{- 2Profitability Rates}

The profitability rate is the net profit after tax due to sales. The company's profitability rate was weak in 1983 , at $4.2 \%$, which is below the industry average of $5 \%$. The profitability rate continued to decline to $0.9 \%$ In 1984 , the rate of profitability of the company continued to decline until it reached about $12.4 \%$ in 1987 . This means that the prices of the company are relatively low or that production costs are high or both.

\section{-3Return on Assets}

This rate measures the effectiveness of the use of the Company's total assets and depends to a large extent on the amount of profits realized from these assets. This rate primarily concerns the investor, showing the return on its investment in the company's total assets. The rate of return on assets is net profit after taxes Total assets of the company. In 1983, this rate was $5.1 \%$, well below the industry average of $10 \%$. This yield resulted in a small percentage of small profits on sales. This rate started to deteriorate in 1984 to $0.95 \%$. Before reevaluating the company's assets at current prices then. In 1985, after the revaluation of the company's assets, the rate was negative $-0.9 \%$ and in 1987 it was $-4.7 \%$ as a result of the significant losses incurred by the company in that year.

Table 8. Financial performance of SATA during the period from 83 to 87

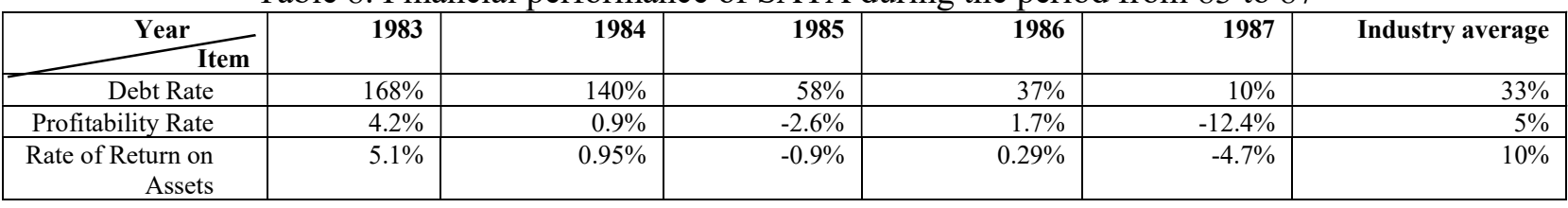

Source: SATA Performance Evaluation Company, 1988

The debt rate of SATA duing the period $1983-1987$

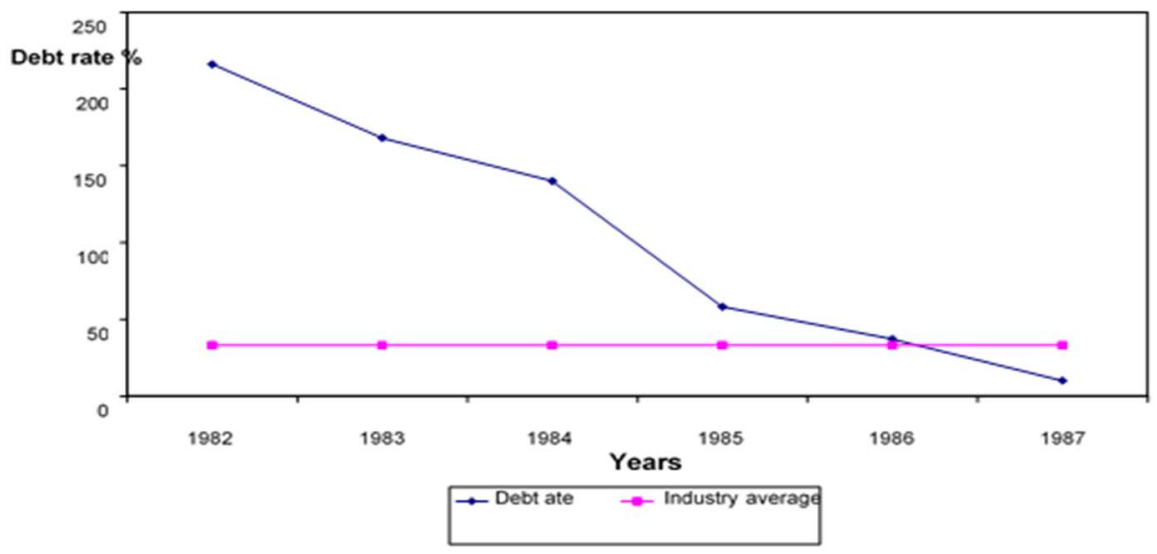

Figure 2. The debt rate of SATA the period 1983-1987 


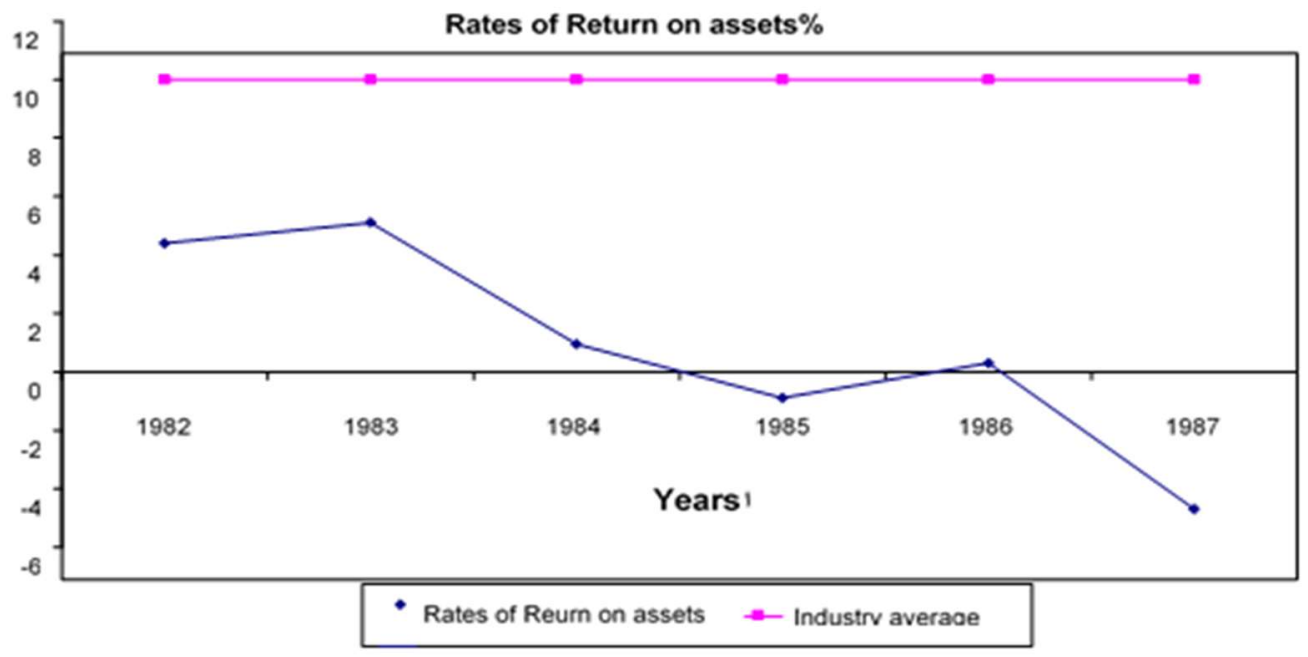

Figure 3. Rates of Return on assets of SATAduring the period 1983- 1987

Source: completed by author.

\subsubsection{Performance evaluation of the company}

As a result of the deteriorating performance of the company as noted during the period of a decade spanning from the beginning of the eighties and until the end of it, and to weaken the company's contribution in support of the State Treasury and its dependence on continuous government support, a technical committee was formed to evaluate the overall performance of SATA by the Ministry of Industry, (15) dated July 11, 1988 issued by the Minister of Industry at that time, where he defined the tasks of the Committee in the study of the financial and administrative performance of the company, and the energy exploited, employment and specializations and problems and constraints faced by the company and its future.

Through the study prepared by the Committee to assess the performance of the company and its future, the Committee concluded that the state ownership of the company was through nationalization and not convinced of the strategic importance of the shoe industry in the country and emerged from the committee charged with studying the following options regarding the future and continuity of the company.(A study on the performance evaluation, Ministry of Industry ,1988,op. Cit.,P.5.(1

\section{First choice :}

The immediate and complete transformation of the company to the private sector by selling government shares to the sector.

\section{the second choice :}

The gradual transformation of the company to the private sector, by selling part of the government shares to the private sector and the right time to exit.

\section{Option 3:}

The Company continues to be a public sector company by acquiring government institutions capable of government shares and providing the necessary financing for the success of the Company's operations. The Committee recommended the second option, which calls for gradual privatization of the company. The technical committee for the management of public sector facilities was formed in 1990 by the Council of Ministers to form technical committees to study, evaluate and evaluate the Sudanese Company for the production and distribution of shoes (Sata) Headed by a delegate from the private sector and three members in the engineering and economic disciplines in preparation for the transformation of the company to the private sector. 


\section{4 - The general performance of the company after privatization}

\section{4-1 Rehabilitation and modernization and its impact on the performance of the company:}

That the unsatisfactory performance of the Sudanese Company for the production and distribution of shoes (Sata) has become clear and clear, or at least untenable, and therefore saw the Sudanese African Investment and Development Company Limited when the management of the company (SATA) after selling them within the privatization program implementation of the rehabilitation plan The company will keep pace with the modern production plans of shoes and even compete in the internal and external markets, especially in light of the policy of economic liberalization adopted by the state, which opened the door wide to enter the products of foreign markets of the country.

The Sudanese African Investment and Development Company has set up a plan to rehabilitate the plant's equipment and machinery by bringing in modern machines and opening new production lines for the production of shoes such as sports shoes that did not already exist in the factory.

By the end of the rehabilitation plan in December 1997, the company started a new stage of production according to plans and programs aimed at achieving profitability for capitalists and increasing productivity and improving quality to gain confidence in the domestic and foreign markets.

However, despite the transformation of the Sudanese Company for the production and distribution of shoes (Sata) to the private sector and the availability of new management of new capital contributed to the rehabilitation to keep pace with the latest methods of production in the shoe industry and its management of a market economy policy aimed at maximizing profit in the first place, However, the company has faced many difficulties and problems after the start of production, which can be identified after reviewing the company's financial and production conditions and measuring the effectiveness of its performance, where it is clear that private sector institutions may face problems and difficulties that limit their productivity as if Public sector institutions.

This confirms that the process of converting productive assets from one hand to another does not imply an increase in production efficiency, because efficiency does not depend on the type of ownership, public or private, but depends on the type of management, which explains the existence of profitable institutions in the public and private sectors.

\subsection{Overall Performance Assessment Company:}

\subsubsection{Production:}

It can be said that the company started production at the beginning of 1998 after the completion of the rehabilitation period for most of the machines in the factory, and because this period enables us to know the rates of productivity and the ability to measure the effectiveness of the performance of the company after rehabilitation and modernization.

Table 9. Production of the company during the period 1998-2002

\begin{tabular}{|c|c|c|c|}
\hline year & $\begin{array}{c}\text { Total Pordution during the } \\
\text { Year }\end{array}$ & $\begin{array}{c}\text { Performance based on Design } \\
\text { power }\end{array}$ & $\begin{array}{c}\text { Performance based on actual } \\
\text { energy }\end{array}$ \\
\hline 1998 & 1049932 & $21 \%$ & $30 \%$ \\
\hline 1999 & 1300109 & $26 \%$ & $37 \%$ \\
\hline 2000 & 1035817 & $21 \%$ & $29.7 \%$ \\
\hline 2001 & 1050805 & $21 \%$ & $30 \%$ \\
\hline 2002 & 1072200 & $21 \%$ & $30.7 \%$ \\
\hline
\end{tabular}

Source: SATA Production Management Company, September 2003.

From the above table we note that the production of the company during the five years from 1998-2002 was very weak as the extent of the independence of the company's production capacity between $30 \%-37 \%$ for actual energy, and between $21 \%$ to $26 \%$ for design power is due to the decline in production and exploitation The production capacity of the

company is that the factory works in one production line, ie, one working rosette for each section in the production departments. This production line represents one third of the design capacity of the factory, which is estimated at about 5,000.000 pairs of shoes in the year, which was reflected in the low production levels of the company To increase the marketing deficit of the company's products It is not competitive to produce 
shoes from foreign markets. Accordingly, the number of working days per week has been reduced to five days and the working hours of the day have increased to 5 O'clock pm.

\subsubsection{Company Productivity Efficiency:}

The efficiency of the production company can be measured after converting it to the private sector according to the previous method we used in the third chapter, which is the calculation of the average productivity of the worker in each of the production divisions of the company, where this indicator can measure the improvement in the productivity of the productive company.

Table 10. The productivity of employees in the various production divisions of the company during the first half of 2003

\begin{tabular}{|c|c|c|c|}
\hline Department & Number of Workers & Production within 6 Months & Workers' wages in 6 months in dinars \\
\hline Plastic & 30 & 536400 & 3845613 \\
\hline Cloth \& Sport & 18 & 47000 & 2351686 \\
\hline Leather & 10 & 9000 & 1531202 \\
\hline Total & 58 & 592400 & 7728502 \\
\hline
\end{tabular}

Source: SATA Production Management Company, September 2003.

From the table above we can calculate the average productivity per worker in each of the production divisions as follows: average productivity of the worker = quantity of output or output divided by the number or size of employment used. The average productivity of the worker in all production divisions of the company has increased since the average productivity of the worker in the sections of shoes (plastic, cloth and leather) was 2980,435 and 150 pairs per month respectively. This is due to the improvement in the productive efficiency of the company and the increase in the average productivity of one worker to the use of modern machines which increased the worker productivity by reducing the number of workers in the machine by 12-2 workers.

\subsubsection{Financial performance of the Company:}

\section{A -Profitability rate:}

The profit rate is the net profit after deduction of production costs and VAT payments attributed to the total sales .The company achieved the highest profitability during the five years ,(2002-1998) which reached 39\%, $49 \%, 51 \%$ and $32 \% .16 \%$ and $16 \%$ respectively over the five years. These rates are well above the industry average average of 5\%,due to the increase in the company's sales during these years and the company's management of a market economy policy aimed at achieving profitability for capitalists.

\section{B- Rate of return on assets:}

The rate of return on assets is the net profit attributable to the total assets of the company. This rate reached the highest level in (2000 - 1999) where it reached $11.5 \%$ and $12.8 \%$ respectively, exceeding the industry average of about 10\% However, in 2001 and 2002, this rate declined significantly, in relation to the profit issue on the company's sales in these two years, which reached $5.4 \%$ and $2 \%$, respectively, which is well below the industry average.

Table 11.The financial performance of the company during the period 1998-2002.

\begin{tabular}{|c|c|c|c|c|c|c|}
\hline Year & $\mathbf{1 9 9 8}$ & $\mathbf{1 9 9 9}$ & $\mathbf{2 0 0 0}$ & $\mathbf{2 0 0 1}$ & $\mathbf{2 0 0 2}$ & Industry average \\
\hline \hline Item & & & & & & \\
\hline Pofitablitity Rate & $99 \%$ & $49 \%$ & $51 \%$ & $32 \%$ & $16 \%$ & $5 \%$ \\
\hline Rate of Return on Assets & $9 \%$ & $11.5 \%$ & $12.8 \%$ & $5.4 \%$ & $2 \%$ & $10 \%$ \\
\hline
\end{tabular}

Source: SATA Financial Performance Assessment in 2003.

\section{Results}

1 -The production of the company during the five years surveyed was much lower than the company's production prior to privatization. See Table (6) and compare it with Table (9). The efficiency of the company's performance on the basis of the actual utilization of energy after privatization was among the highest of $\% 30$ Much lower than the pre-privatization capacity, which ranged between the highest rate of $51 \%$ and the lowest rate of $27 \%$.

Therefore, it can be said that the policy of privatization of SATA has not yet come to fruition despite the provision of capital for modernization and rehabilitation, as this was not reflected in the increase in the production and production capacity of the company and therefore the company remained as if it was a public 
sector company before privatization in 1993 . This refutes the initial hypothesis of research that The change of ownership leads to the promotion and increased trade competition of state-owned enterprises, resulting in improved financial performance and productive efficiency.

2 -The efficiency of the production company and the average productivity of the worker has seen a remarkable improvement after the privatization of the company thanks to the use of modern machines, which increased the productivity of the worker by reducing the number of workers in the machine one, and therefore can say: the low productivity of the company in the past Is largely due to the increase in the number of workers in the production machinery. This supports the third hypothesis of research that private sector institutions attract and use their financial and human resources more efficiently than public sector institutions.

/ 3Financial performance of the company:

\section{A -Profitability Rates:}

It can be said that the company achieved significant profits in its production after the qualification stage. The company achieved its highest profit in the year of $(200 \%)$, which amounted to $51 \%$ of the total sales value. This was due to the increase in the quantity of sales this year, In the years 2001-2002, due to the very low sales of the company due to the increase of the marketing deficit in these two years.

Therefore, the profitability of the company during the five years covered by the study is attributed to the privatization of the company when the company was under the management of the public sector where it achieved very low profitability rates and in some cases loss as in the years $85-1987$.This supports the hypothesis of the second research based on The profitability of state-owned enterprises is less than that of privately owned enterprises.

\section{$B$-Rate of return on assets:}

We find that after privatization, the company achieved a return on its assets that exceeded the average of the industry in the years (99 and 200 ,(0unlike the years before privatization ( 83 - 198 , (7where the rate of return on the assets of the company is very weak and much lower than the average industry average.Tabe (8) compared to Table (11), but this rate started to decline in the years 2001-2002 to below the average due to the deterioration in the profits of the company in these two years.

\section{Recommendations}

1 -The researcher recommends not to privatize public institutions by selling off the old debts owed by the state, as is the case in the SATA company, because the owners of these debts are the first concern to obtain the guarantee to repay their debts in the form of fixed assets and not to work to support the production process and the economy.

2 -The state must follow a protectionist policy that helps the private sector to promote the local market with its products first and then enable it to compete later in the foreign markets.

3 -When applying the policy of privatization to any institution must be kept in mind a minimum reduction in the number of employment in that institution so as to harm workers as is the case in the company SATA.

4 -The state should gradually take the process of transferring public institutions to the private sector by not exposing a large number of institutions for sale at the same time, because this reduces their market value because of the limited capacity of the local market.

5 -The state must create a sound environment conducive to the process of privatization and depends on the development of the stock market to the extent that allows the circulation of shares and bonds in the case of sale and purchase and the adjustment of tax structures that help to stimulate the private sector to invest.

6 -The State shall create new job opportunities for the unemployed workers who are excluded from the privatization program or train them to acquire new skills or to provide them with capital that enables them to establish individual production projects.

\section{References}

First: References and books:

1. Ahmed Maher (2002). Director's Guide to Privatization, University House, Alexandria. 
5 -Steve Hankey: Transforming Public Property into Private in the East, West and Economic Development, Dar Al Shorouk.

6 -Fred Weston and Yohine Burjam. (1993). Administrative Finance Part I, Daral - Marikh Saudi Arabia.

7 -Dia Majid. (2003). Privatization and Structural Corrections (Opinions and Trends), University Youth Foundation, Alexandria.

8- Kabbashi Nasser: Director of Marketing Department, SATA, interview dated 21/9/2003.

9 -A study on the performance evaluation of the Sudanese Company for Production and Distribution of Shoes Ltd., Ministry of Industry, 1988.

11 -Mohamed Hashim Awad: A Symposium on the Policies of Economic Liberalization Sudan Experience, Sharjah Hall, 25-27 / 11/1995.

12 -Memorandum of sale of SATA and Blue Nile Packaging Company, prepared by Mubarak Khaled Musa, Coordinator of the General Industrial Sector, 1994.

13 -Naamat Al-Fadil, Working Paper on Privatization in Sudan from an Administrative Perspective, Sharjah Hall, 8-9 November 1997.

14 -Working Paper on Privatization in Sudan Standards and Procedures for the Disposal of Facilities in the Public Sector, Sharjah Hall 8-9 November 1997.

15 -Fatima Ahmed Mohamed. (1995). The Role of Privatization in Improving the Performance of an Establishment, Unpublished Master 's Thesis, University of Khartoum,

16 -Report of the Technical Committee for Public Sector Utilities, 2000.

3 -Said Alnajjar. (December 1988). Privatization and structural corrections in Arab countries, Arab Monetary Fund.

10 -Taj Al-Din Ibrahim Hamed. (September 1997). Journal of Banker, 12, issued by the Bank of Sudan.

11. Said Ismail Ali. (October 1997). Education and Privatization, Al-Ahram Economic Book, 105.

12. Mohamed El-Tayeb Abdullah (May 2001). The Experiment of Fertilization in Sudan, Institute of Economic and Social Research, Khartoum. 